УДК 27-29

https://doi.org/10.18485/godisnjak.2017.12.4

\author{
Зорица С. Витић* \\ Универзитет у Београду \\ Филолошки факултет
}

Оригинални научни рад

Примљен: 6. 10. 2017.

Прихваћен: 23. 10. 2017.

\title{
О ЈЕДНОЈ МАРГИНАЛИЈИ ПРЕПИСИВАЧА АВЕРКИЈА
}

Књижевна сарадња словенских монаха на Атосу почетком XV века посведочена је и преводом „Слова постничаског по вапросу и ответу”

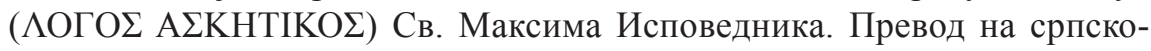
словенски сачинио је Јаков Доброписац 1425. године у светогорском манастиру Светог Павла, а наручилац је познати руски преписивач тога времена, Јевсевије Јефрем „Русин”. Оригинал није сачуван, али преписи овог састава убрзо настају и у руској и у светогорској (хиландарској) средини. Узгредно сведочанство о трајном сећању на ову сарадњу оставио је монах Аверкије у панагирику за месец јануар, који је преписао у Кареји 1626. године (Хил. 443).

Кључне речи: Максим Исповедник, Подвижничко слово, српскословенски превод, Јаков, Јевсевије Јефрем, Света Гора, Русија, Хиландар, преписивач Аверкије.

У време турских освајања учени монаси, талентовани писци и преводиоци уточиште су тражили на западу, у српској деспотовини ${ }^{1}$, некада

*zv2207@gmail.com

${ }^{1}$ Поред изузетних књижевника тога времена, Григорија Цамблака, Константина Филозофа, Андонија Рафаила Епактита, велики углед уживали су преводиоци и преписивачи из Трнова и са Свете Горе, а неки од њих оставили су у записима значајне појединости које илуструју схватање самог преписивачког рада, или пак историјске околности које га прате и одређују. Тада настају и бројни нови преводи са грчког на српскословенски, често потписани и датирани, а Стефан Лазаревић јавља се и као њихов наручилац (о деспотовом односу према књижевности и књигама в. Трифуновић 1979: 77-98). 
су стизали чак до Русије, или се задржавали у још неосвојеном Цариграду. Ипак, Света Гора, као „духовни центар Источног Римског царства” (Мошин 1947: 56), и тада је била њихово главно стециште, сигурно, свето место на којем се и даље могла несметано одвијати жива књижевна делатност и сарадња знаних и незнаних словенских монаха (Собољевски 1903: 8-14; Мошин 1963: 101, 104; Дујчев 1963: 121-126).

Један потписани превод илуструје занимљиве српско-руске културне везе почетком XV века. Наиме, у атонском манастиру Светог Павла ${ }^{2}$ образовао се врсни преписивач и преводилац Јаков ${ }^{3}$, који је 1425 . године превео са грчког на српскословенски ${ }^{4}$ „Слово постничаско по вапросу и ответу"5 Максима Исповедника, једног од најзначајнијих византијских теолога (580-662). То је учинио на захтев познатог руског преписивача ${ }^{6}$, Јевсевија Јефрема „Русина”", који је из Цариграда, где је боравио у манастиру Богородице Перивлепте преписујући Минеј и Лествицу (1420/21), прешао на Свету Гору, у манастир Ватопед, а потом вероватно у манастир Светог Павла (Вздорнов 1968: 178-179). Тамо је могао срести преписивача и преводиоца Јакова и затражити од њега овај превод. Зборник из 1425. године није сачуван, али се у библиотеци Тројице-Сергијеве лавре чувају

2 Захваљујући двојици угледних српских монаха (Роману/Герасиму, брату Вука Бранковића, и Антонију, из врањске властелинске породице Багаш), на земљишту запустелог грчког подигнут је нови манастир Светога Павла око 1380. године (Суботић 1983: 207-258).

${ }^{3}$ Највероватније је да је управо он 1418. године сачинио препис Слова Григорија Богослова за Павла, некадашњег игумана св. Арханђела код Призрена, и Ђурђа Бранковића (Трифуновић 2009: 210-211), као и једну књигу Беседа Јована Златоустог, у манастиру Светог Павла 1426. године (ГИМ Син. 36, в. Вздорнов 1968: 178). Могућности ових поистовећивања разматра А. А. Турилов (Турилов 2011: 165, 189-190; Турилов 2014: 310-311).

${ }^{4}$ Архиепископ Филарет (Гумиљевски) сматрао је да је превод дело неког руског или бугарског монаха који је дуго боравио на Атону (Прохоров 1989: 369).

${ }^{5}$ Слово се састоји од 45 глава у облику „питања и одговора”. То је, заправо, дијалог брата (монаха-подвижника) и старца (духовног оца) о аскетском путу и достизању духовног савршенства. Издање грчког текста: PG 90: 912-956. Превод на савремени српски језик начинио је епископ Артемије Радосављевић (Свети Максим Исповедник 1997: 127-162). Философским и теолошким погледима Св. Максима Исповедника посвећен је читав број часописа Луча, а тада је прештампан и грчки изворник и српски превод Слова (Луча 2006: 62-87). Захвалност за помоћ у проналажењу извора дугујем драгом колеги Данијелу Дојчиновићу са Филолошког факултета у Бањалуци.

${ }^{6}$ Занимљиву идентификацију предложио је Ђ. Трифуновић на основу записа у рукопису насталом у цариградском манастиру Богородице Перивлепте (после 1402. године, в. Стојановић 1923: 21, бр. 6107): Јевсевије је био пореклом Србин, који се, бежећи од „турског цара Илдирим Бајазита", обрео на Светој Гори и тамо замонашио, потом боравио у Цариграду и касније поново прешао на Атон (Трифуновић 2009: 331-332).

${ }^{7}$ О свим Јевсевијевим преписима в. исцрпну одредницу у Православној енциклопедији (Турилов 2013: 277). 
два ${ }^{8}$ рукописа, веома блиска по времену настанка, која садрже преписе Слова са записом о преводиоцу, кир Јакову Доброписцу, и наручиоцу,

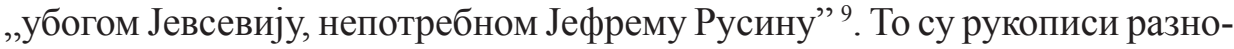
лике аскетске садржине (РГБ Ф. 304/1 бр. 756, с почетка друге четвртине XV века и рукопис РГБ Ф. 304/1 бр. 175, настао пре 1431. године) $)^{10}$, са преводима или редакцијама превода насталих на јужнословенском терену y XIV и почетком XV века. Због тога, као и због правописних одлика, ови преписи прави су пример „другог јужнословенског утицаја” на средњовековну руску писменост у књижевност ${ }^{11}$.

Рукописна традиција словенског превода Слова Максима Исповедника наставља се и на Светој Гори. Српскословенски препис, идентичан руским, налази се у хиландарском зборнику монашко-исихастичког типа $(\text { бр. 278) })^{12}$, из средине XV века. Ђорђе Трифуновић с правом сматра да се на последњим листовима, који сада недостају, налазио и запис о пореклу Слова (Трифуновић 2009: 211). Извесно је, дакле, да се, двадесетак година касније, Јаковљев превод чувао и преписивао у српској монашкој средини, највероватније у Хиландару.

Једна преписивачка маргиналија у готово два столећа млађем хиландарском рукопису неочекивано је потврдила ове претпоставке. Наиме, у панагирику за месец јануар ${ }^{13}$ (Хил. 443, Богдановић 1978: 170-171), који

${ }^{8}$ Релативно бројне, нешто позније руске преписе наводи Прохоров 1989: 369.

9 Запис према руском препису РГБ Ф. 304/1 бр. 756, л. 3626-363a: „По въпросу и ответу постничьскому Слово св. Максима преводено от гречьска языка на русийскый в святей горе Афонстей в лето 6933 (1425) кир Иаковом доброписцем убогому Евсевию, непотребному Ефрему Русину" (http://old.stsl.ru/manuscripts/book.php?col=1\&manuscript=756).

${ }^{10}$ У првом препису, највероватније насталом у Тројице-Сергијевој лаври, Слово на л. 344a-3626 (http://old.stsl.ru/manuscripts/book.php?col=1\&manuscript=756). Други препис је из Лисицког манастира посвећеног Рођењу пресвете Богородице, близу Новгорода, Слово на л. 402a-420б, са истим записом на крају (http://old.stsl.ru/manuscripts/book.php?col=1\&manuscr $\mathrm{ipt}=175$ ).

${ }^{11}$ Попис литературе о „другом јужнословенском утицају” доноси Ђ. Трифуновић (Трифуновић 2009: 326). Најновији допринос проучавању овог значајног питања дао је А. А. Турилов (Турилов 2014: 307-326).

${ }^{12}$ Овај рукопис занимљивог састава започиње Паладијевим Лавсаиком, следи Житије Св. Антонија Великог, потом два слова на Рођење Претече (Антипатра Востронског и Атанасија Великог), Слово на Успеније Богородице Григорија Паламе и Богородичино чудо у обитељи Велика заступница. У другом деิлу такође доминирају аскетски садржаји: скитски устав, изводи из патерика, исихастички списи (О животу иночком и о осам помисли, О тајни умног делања и о молитви укратко патријарха Калиста), поучна слова Анастасија Синаита, Петра Дамаскина, Јефрема Сирина, и Слово постничаско по вапросу и ответу Максима Исповедника (Богдановић 1978: 124; Лазић 1990: 219-242; Витић 2015: 37-40).

${ }^{13}$ Рукопис је део Чти-минеја (потпуног комплета зборника житија и слова за читаву годину), јединственог у јужнословенској традицији, насталог на иницијативу хиландарског игумана Илариона. Аверкије је, наиме, од 1622. до 1626. године саставио и преписао шест 
је монах Аверкије завршио у Карејском пиргу 1626. године, након преписа „Житија св. Антонија Великог”, на л. 344б, налази се завршна напомена: „таже въ росину”. Како смо утврдили да је препис Антонијевог житија морао бити сачињен управо према старијем хиландарском рукопису (Витић 2015: 40) ${ }^{14}$, постаје јасно да је Аверкије у краткој маргиналији именовао свој предложак, и тако открио да је читав хиландарски зборник из XV века носио назив према „Русину”, изврсном руском преписивачу Јевсевију Јефрему, наручиоцу превода Слова Максима Исповедника.

Скраћенице:

ГИМ Син. - Государственный Исторический Музей, Москва, Синодальное (Патриаршее) собрание

РГБ - Российская государственая библиотека, Москва

Хил. - Рукописна збирка манастира Хиландара

\section{ИЗВОРИ}

Луча 2006: APHE KAI TE $\Lambda \mathrm{O} \Sigma$. Аспекти философске и теолошке мисли Максима Исповедника, Луча XXI-XXII (2004-2005), Никшић 2006, $62-87$.

Свети Максим Исповедник 1997: Свети Максим Исповедник, Изабрана дела. 400 глава о љубави. Подвижничко слово. Мистагогија. Превео са грчког оригинала епископ рашко-призренски Артемије, Призрен 1997, 127-162.

PG 90: J. P. Migne, Patrologiae cursus completus. Series Graeca, XC, Paris $1865,912-956$.

\section{ЛИТЕРАТУРА}

Богдановић 1978: Д. Богдановић, Каталог ћирилских рукописа манастира Хиландара, Београд.

Вздорнов 1968: Г. И. Вздорнов, Роль славянских монастырских мастерских письма Константинополя и Афона в развитии книгописания и

импозантних кодекса (Хил. 439-444; уп. Богдановић 1978: 168-172; Томсон 2014: 89-143). У њима су, уз оригиналну књижевност, сачувани и најстарији словенски, моравски преводи, заједно са четрнаестовековним трновским и атонским новим преводима (Иванова 2003: 322).

${ }^{14}$ Сам крај житија јединствен је у овим двама преписима. Уобичајеном тексту додат је, по свему судећи, тропар посвећен св. Антонију, вероватно из општег минеја или из месецослова. 
художественного оформления русских рукописей на рубеже XIV-XV вв., Труды Отдела древнесусской литературы, XXIII, Ленинград, 177-179, 193-196.

Витић 2015: 3. Витић, „Житије светог Антонија Великог” према српским средюовековним рукописима, Београд.

Дујчев 1963: И. Дуйчев, „Центры византийско-славянского общтрния и сотрудничества”, Труды Отдела древнерусской литературы, XIX, Москва-Ленинград, 107-129.

Иванова 2005: К. Иванова, Хилендарски чети-минеи на монах Аверкие от XVII в., България и Србия в контекста на византийската иивилизация. Сборник статии от българо-сръбски симпозиум 14-16 септември 2003, София, 313-327.

Лазић 1990: М. Лазић, Слово на Успење Богородице Григорија Солунског (Паламе) у оквиру Хиландарског српског зборника из XV века, Археографски прилози 12, Београд, 219-242.

Мошин 1947: В. Мошин, Руские на Афоне и русско-византийские отношения в XI-XII вв., Byzantinoslavica IX, Prag, 54-85.

Мошин 1963: В. Мошин, О периодизации русско-южнославянских литературных связей X-XVвв., Труды Отдела древнерусской литературы, ХІХ, Москва-Ленинград, 28-106.

Прохоров 1989: Г. М. Прохоров, „Иаков Доброписец”, Словарь книжников и книжности Древней Руси, вып. 2, ч. 1, Москва, 369.

Собољевски 1903: А. И. Соболевский, Южно-славянское вліяніе на русскую письменность въ XIV-XV въкахъ. У: „Переводная литература Московской Руси XIV-XVII вв.”, Извъстия отделения русского языка и словесности Императорской Академии наукъ, T. LXXIV, № 1, СПб, 1-37.

Стојановић 1923: Љ. Стојановић, Стари српски записи и натписи, књ. IV, Сремски Карловци.

Суботић 1983: Г. Суботић, Обнова манастира Светог Павла у XIV веку, Зборник радова Византолошког института 22, 207-258.

Томсон 2014: F. J. Thomson, Abercius. The Principal Scribe of the Hilandar Menologium, the Largest Extant South Slav Menologium, Analecta Bollandiana, t. 132, I, 89-143.

Трифуновић 1979: Ђ. Трифуновић, Живот, доба и књижевни рад Стефана Лазаревића. У: Деспот Стефан Лазаревић, Кьижевни радови, Београд, 7-141.

Трифуновић 2009: Ђ. Трифуновић, Стара српска књижевност. Основи. Треће, проширено издање, Београд. 
Турилов 2011: А. А. Турилов, Южнославянские переводы XIV-XV вв. и корпус переводных текстов на Руси (к 110-летию выхода в свет труда А. И. Соболевского), у: От Кирилла Философа до Константина Костенецкого и Василия Софиянина (История и культура славян IX-XVII веков), Москва, 161-200.

Турилов 2013: А. А. Турилов, Евсевий-Ефрем, у: Православная Энциклопедия под редакциией Патриарха Московского и всея Руси Кирилла, T. XVII, Москва, 277 (http://www.pravenc.ru/text/187378.html).

Турилов 2014: А. А. Турилов, К вопросу о сербском компоненте во «втором южнославянском влиянии, у: Исследования по славянскому и сербскому средневековью, Београд, 307-326.

Zorica S. Vitić

ON ONE MARGINALIA OF SCRIBE ABERCIUS

\section{Summary}

Intensive literary cooperation between Slavic monks on Mount Athos in the beginning of the $15^{\text {th }}$ century is also corroborated by the translation of Maximos Homologetes' $\Lambda$ ОГО $\Sigma$ A $\Sigma$ KHTIKO $\Sigma$. Serbian Slavonic translation was composed by Jacob "Dobropisac" in 1425, in the Athonite monastery of St. Paul, and ordered by Eusebius Ephraim "Russian", famous Russian scribe of the time. The original manuscript is not preserved, but its copies exist both in the Russian and in the Athonite monastic centers (Hilandar). One marginalia in the Hilandar menologium with January, written by monk Abercius at Karyes on Athos in 1626 (Hilandar Monastery, codex 443), is a late, unexpected testimony of the lasting memory of this literary cooperation.

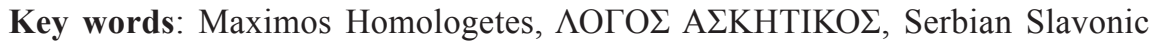
translation, Jacob "Dobropisac", Eusebius Ephraim "Russian", Mount Athos, Russia, Hilandar, scribe Abercius 


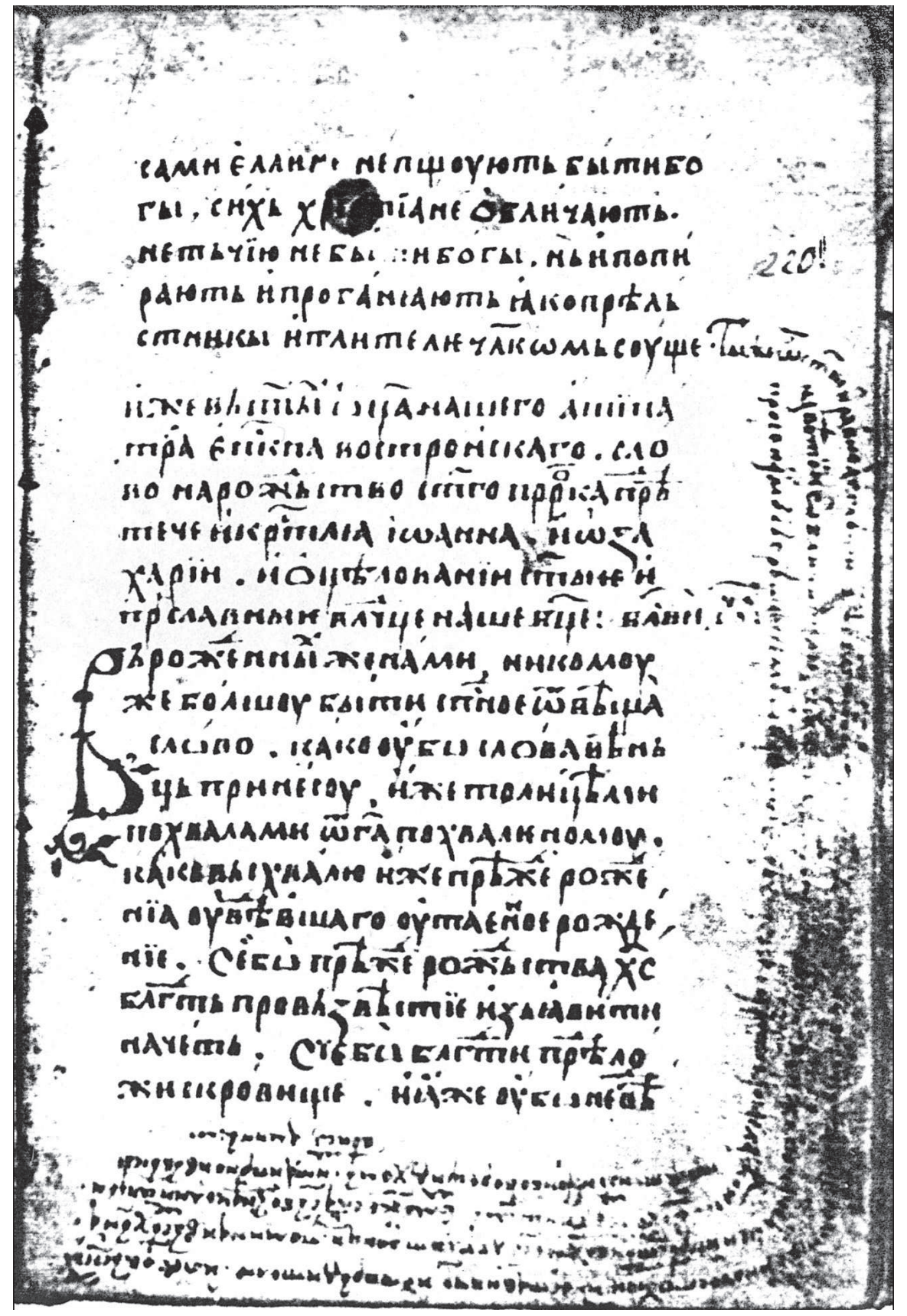

Крај Житија светог Антонија (Хил. 278), средина XV века, л. 220а 
$\therefore t$

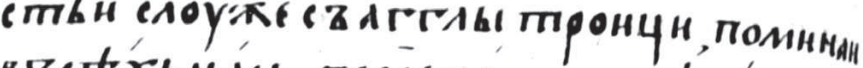

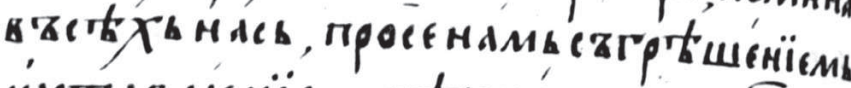

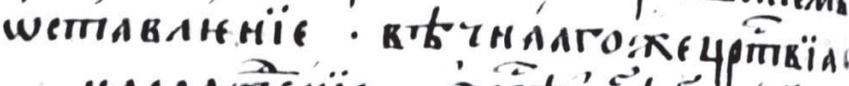

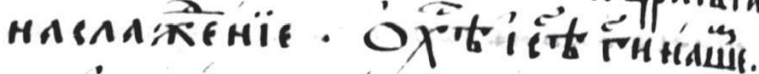

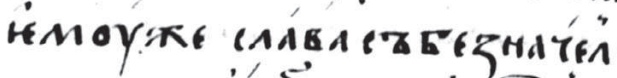

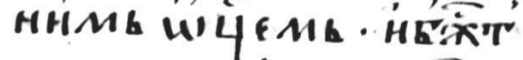
BHLIMG H'RHEOTÉ речнмй̈̈о HHHHTPH HO H $\mathbf{a z B}$

$15 \overline{61}$

at

iso

in

is

n

?

$\dddot{t}$

Taike azpochers.

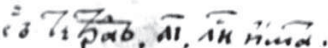
MT

Аверкијев панагирик јануарски из 1626. године (Хил. 443), л. 3446 